\title{
K MOŽNOSTI NAHRAZENÍ VLASTNORUČNÍHO PODPISU ZAMĚSTNAVATELE NA VÝPOVĚDI Z PRACOVNÍHO POMĚRU MECHANICKÝMI PROSTŘEDKY
}

\author{
LUBOMÍR PTÁČEK*
}

\begin{abstract}
On the Possibility of Substitution of the Employer's Handwritten Signature on the Notice of Dismissal by Mechanical Means

It is only possible to replace the acting person's signature on the written expression of will by mechanical means (e.g. by stamp, facsimile, reproduction of the signature on the form) where this is customary. The customary nature of the case must be assessed objectively, taking into account the nature of the legal act in question and, in the context of labor law relations, also emphasizing the principle of special legal protection of the employee status. In the case of unilateral legal acts of an employer aimed at terminating an employment relationship with an employee, it is necessary to emphasize in particular the seriousness of these legal acts and their ability to bring about the termination of the basic employment relationship, often to the detriment of the employee. In these cases - irrespective of their frequency with a particular employer - it is therefore highly desirable to guarantee that the act to terminate the employment is actually done and signed by the authorized person, which can only be ensured by manifestation of will culminating in the employer's own signature. Therefore, in a written unilateral legal act of the employer aimed at terminating the employment relationship with the employee, the handwritten signature of the employer cannot be replaced by mechanical means; this legal act must always be signed by the employer (his statutory body or another person authorized to act on behalf of the employer), otherwise it is void.
\end{abstract}

Keywords: termination notice; electronic signature; mechanical means

Klíčová slova: výpověd’ z pracovního poměru; elektronický podpis; mechanické prostředky

DOI: $10.14712 / 23366478.2021 .8$

Rozvázání pracovního poměru jednostranným pracovněprávním jednáním zaměstnavatele představuje pro zaměstnance zásadní životní změnu s neblahým dopadem do jeho osobních a ekonomických poměrů. Zákoník práce vychází ze zásady bezformálnosti pracovněprávních jednání, ledaže je zákonem předepsáno nebo smluvními stranami základních pracovněprávních vztahů (jinými subjekty pracovněprávních vztahů) dohodnuto, že smí být učiněno pouze písemně. Mezi pracovněprávní jednání,

\footnotetext{
Autor je předsedou senátu Nejvyššího soudu a prezidentem Evropské asociace soudců pracovněprávních soudů (The European Association of Labour Court Judges).
} 
u nichž zákon vyžaduje písemnou formu, patři mimo jiné i výpověd’ z pracovního poměru, její odvolání a souhlas s jejím odvoláním (\$ 50 odst. 1 a 5 ZPr), okamžité zrušení pracovního poměru ( $\$ 60$ ZPr) nebo zrušení pracovního poměru ve zkušební době ( $\$ 66$ odst. 2 ZPr), tedy ta pracovněprávní jednání, jimiž se rozvazuje pracovní poměr. K náležitostem písemné formy pracovněprávního jednání patří i vlastnoruční podpis listiny, v němž je pracovněprávní jednání zachyceno, ledaže by byl - tam, kde je to obvyklé - nahrazen mechanickými prostředky, např. podpisovým razítkem nebo reprodukcí vlastnoručního podpisu.

Občanskoprávní a obchodní kolegium Nejvyššího soudu se na jednání v prosinci roku 2019 zabývalo otázkou, ${ }^{1}$ zda na písemném právním úkonu zaměstnavatele směřujícím k rozvázání pracovního poměru výpovědí může být podpis zaměstnavatele nahrazen mechanickými prostředky. Terminologická odlišnost v popisu právního jednání plyne z toho, že výpověd’ byla zaměstnanci doručena dne 28. 2. 2012, tj. jednak před nabytím účinnosti ObčZ, ${ }^{2}$ ale již v době účinnosti ZPr. ${ }^{3}$ Protože tato právní otázka dosud nebyla v rozhodování Nejvyššího soudu za účinnosti ZPr vyřešena, bylo dovolání žalobce proti usnesení odvolacího soudu shledáno za přípustné a po přezkoumání napadeného usnesení i za opodstatněné.

V předmětné věci žalovaná dopisem ze dne 28. 2. 2012, který byl žalobci (zaměstnanci) doručen téhož dne, sdělila žalobci, že mu dává výpověd’ z pracovního poměru podle ustanovení $§ 52$ písm. c) ZPr. Důvod výpovědi spatřovala v tom, že se žalobce „vzhledem k rozhodnutí zaměstnavatele z dně̌ního dne stal pro žalovanou nadbytečným “, nebot' ,jeho pracovní místo (technická podpora) se ruší z di̊vodu organizační změny “. Výpověd’ byla opatřena otiskem podpisového razítka A. Z., předsedy představenstva žalované. Soud prvního stupně žalobě vyhověl a s poukazem na ustálenou judikaturu dovolacího soudu, podle níž je třeba jednostranný právní úkon směřující k rozvázání pracovního poměru vždy opatřit vlastnoručním podpisem jednající osoby, dospěl k závěru, že předmětná výpověd’ ze dne 28. 2. 2012 „,je pro nedostatek formy právního úkonu neplatná ve smyslu ust. § 20 odst. 3 ZPr“. Námitku žalované, že podle ustanovení $§ 40$ odst. 3 ObčZ 1964, lze nahradit podpis mechanickými prostředky $\mathrm{v}$ případech, kdy je to obvyklé, odmítl s odůvodněním, že takováto forma podpisu je přípustná např. v bankovním či finančním sektoru, kde to vyžaduje efektivita masového právního styku, avšak v daném případě se ,rozhodně o masový styk nejednalo, a proto nahrazení vlastnoručního podpisu mechanickými prostředky přípustné není".

Odvolací soud rozsudek soudu prvního stupně k odvolání žalované (zaměstnavatele) zrušil a věc mu vrátil k dalšímu řízení. Vytkl soudu prvního stupně, že sice použil správné ustanovení $§ 50$ odst. 1 a $§ 20$ odst. 1 ZPr ve spojení s ustanovením $\S 40$ odst. 3 ObčZ 1964, jehož subsidiární použití umožňovalo ustanovení § 4 ZPr, následně však nesprávně aplikoval judikaturu dovolacího soudu, jestliže absolutně vyloučil možnost podpisu výpovědi z pracovního poměru mechanickými prostředky, konkrétně otiskem

\footnotetext{
Usnesení Nejvyššího soudu ze dne 18. 12. 2018, sp. zn. 21 Cdo 682/2018.

Tedy za účinnosti ObčZ 1964 - zákona č. 40/1964 Sb., občanský zákoník, ve znění účinném do 13. 6. 2012, tj. přede dnem, kdy nabyl účinnosti zákon č. 170/2012 Sb.

3 Zákon č. 262/2006 Sb., zákoník práce, ve znění účinném do 31. 3. 2012, tj. přede dnem, kdy nabyl účinnosti zákon č. 375/2011 Sb.
} 
podpisového razítka statutárního orgánu žalované. Podle názoru odvolacího soudu však i v př́ípadě podpisu výpovědi z pracovního poměru lze o takové možnosti uvažovat, jsou-li k tomu splněny zákonné předpoklady uvedené v ustanovení § 40 odst. 3 ObčZ 1964, tedy je-li to obvyklé. Soudu prvního stupně proto uložil, aby v dalším řízení zkoumal, zda v rozhodném období bylo u žalované „obvyklou praxí nahrazovat mechanickým prostředkem vlastnoruční podpis statutárního orgánu žalovanév př́padech ukončování pracovního poměru se zaměstnanci“.

Soud prvního stupně žalobě opět vyhověl s tím, že po doplnění řízení dospěl k závěru, že s ohledem na velké množství písemných pracovněprávních úkonů bylo u žalované nahrazování vlastnoručního podpisu statutárního orgánu žalované na pracovněprávních dokumentech mechanickými prostředky obvyklou praxí, a proto „z tohoto důvodu výpověd' neplatná není “. Podle názoru soudu prvního stupně je však předmětná výpověd z pracovního poměru neplatná pro nenaplnění uplatněného výpovědního důvodu, nebot' z provedených důkazů „,nelze dojít k závěru o nadbytečnosti žalobce ke dni 28.2.2012“.

Odvolací soud se v následném rozhodnutí mimo jiné ztotožnil s názorem soudu prvního stupně, že užití podpisového razítka žalovanou na pracovněprávních dokumentech bylo v její praxi obvyklé, a že proto „po formální stránce lze výpověd’ považovat za rádnou “. Proti tomuto závěru brojil žalobce dovoláním, v němž namítal, že odvolací soud nesprávně použil na pracovněprávní vztah účastníkủ ustanovení $\$ 40$ odst. 3 ObčZ 1964, jehož užití vylučovalo znění ustanovení § 18 ZPr účinné $\mathrm{k}$ datu předmětné výpovědi. $Z$ tohoto důvodu pak odvolací soud nesprávně posoudil možnost žalované použít na výpovědi dané žalobci dne 28. 2. 2012 podpisové razítko. Podle názoru dovolatele „neexistuje“ v rozhodovací praxi Nejvyššího ani Ústavního soudu takové rozhodnutí, které by podpořilo závěr odvolacího soudu o přípustnosti nahrazení vlastnoručního podpisu jednající strany mechanickými prostředky na výpovědi z pracovního poměru dané zaměstnavatelem zaměstnanci $v$ době předmětné výpovědi.

Nejvyšší soud předně připomněl, že podle ZPr ve znění účinném do 31.3. 2012 je zapotřebí posuzovat jak splnění podmínek platné výpovědi z pracovního poměru podle ustanovení § 52 písm. c) ZPr, tak také podmínky možného subsidiárního použití ObčZ 1964. ${ }^{4}$ Výpověd z pracovního poměru daná zaměstnavatelem zaměstnanci je právním úkonem, vztahují se proto na ni ustanovení $§ 18$ až 20 ZPr a subsidiárně též ustanovení $\S 34$ až 51 hlavy čtvrté o právních úkonech ObčZ 1964. Není tak důvodná námitka, že na danou věc „,nebylo možno aplikovat ustanovení \$ 40 odst. 3 ObčZ 1964“. Zároveň však nelze opomenout, že řídí-li se pracovněprávní vztahy občanským zákoníkem, musí to být vždy v souladu se základními zásadami pracovněprávních vztahů (srov. § 4 větu za středníkem ZPr), přičemž jednou ze základních zásad pracovněprávních vztahů je zvláštní zákonná ochrana postavení zaměstnance [srov. § 1a odst. 1 písm. a) ZPr]. Proto

4 Jak vyplývá z ustanovení § 4 zák. práce, pracovněprávní vztahy se řídí tímto zákonem; nelze-li použít tento zákon, řídí se občanským zákoníkem, a to vždy v souladu se základními zásadami pracovněprávních vztahů. Pro pracovněprávní vztahy se nepoužijí ustanovení občanského zákoníku o smlouvě ve prospěch třetí osoby, o zadržovacím právu, o vymíněném odstoupení od smlouvy, o společných závazcích a právech, o smlouvě s přesnou dobou plnění a o postoupení pohledávky (srov. § 4a odst. 1 zák. práce). 
také dovolací soud při výkladu ustanovení ObčZ 1964 postupoval v souladu i s výše uvedenou zásadou.

K možnosti nahradit vlastnoruční podpis na výpovědi z pracovního poměru mechanickými prostředky Nejvyšší soud uvedl, že možnost nahrazení podpisu jednající osoby na písemném projevu vůle mechanickými prostředky (nap̌r. razítkem, faksimile, reprodukcí podpisu na tiskopise) přichází v úvahu pouze v případech, kdy je to obvyklé. Obvyklost případu je přitom třeba posuzovat objektivně (srov. usnesení Nejvyššího soudu ze dne 10. 1. 2001, sp. zn. 25 Cdo 176/99), s přihlédnutím k charakteru dotčeného právního úkonu a v pracovněprávních vztazích též s důrazem na zásadu zvláštní zákonné ochrany postavení zaměstnance [srov. § 1a odst. 1 písm. a) a $§ 4 Z \mathrm{ZPr}$ ]. V případě jednostranných právních úkonů zaměstnavatele směřujících k rozvázání pracovního poměru se zaměstnancem je nutno při tomto posouzení akcentovat zejména závažnost těchto právních úkonů a jejich způsobilost (schopnost) přivodit zánik základního pracovněprávního vztahu, nezřídka na újmu adresáta tohoto úkonu (zaměstnance). V těchto př́padech - bez ohledu na jejich četnost u konkrétního zaměstnavatele - je proto nadmíru žádoucí zaručit, aby právní úkon směřující k rozvázání pracovního poměru učinila (a podepsala) skutečně ta osoba, která je k němu oprávněna, což lze zajistit pouze tehdy, je-li písemný projev vůle završen vlastnoručním podpisem zaměstnavatele (jeho statutárního orgánu nebo jiné osoby oprávněné jednat za zaměstnavatele). Z těchto důvodů je tedy opodstatněn závěr, že na písemném jednostranném právním úkonu zaměstnavatele směřujícím k rozvázání pracovního poměru se zaměstnancem nemůže být vlastnoruční podpis zaměstnavatele nahrazen mechanickými prostředky; tento právní úkon musí být vždy vlastnoručně podepsán zaměstnavatelem (jeho statutárním orgánem nebo jinou osobou oprávněnou jednat za zaměstnavatele), jinak je neplatný.

Jako obiter dictum Nejvyšší soud připomněl, že o tom, že nahrazování vlastnoručního podpisu zaměstnavatele mechanickými prostředky na písemných jednostranných právních úkonech směřujících k rozvázání pracovního poměru není (ani dříve nebylo) v pracovněprávních vztazích obvyklé, ostatně svědčí i doposud obecně přijímané závěry, které dovodila judikatura Nejvyššího soudu ve vztahu k ZPr $1965,{ }^{5}$ který neumožňoval subsidiární použití občanského zákoníku. Jako jedna z náležitostí písemné formy jednostranného právního úkonu směřujícího k rozvázání pracovního poměru byl i zde vysloven požadavek (srov. právní názor vyslovený v rozsudku Nejvyššího soudu ze dne 4. 12. 1996, sp. zn. 2 Cdon 833/96, uveřejněném pod č. 5 v časopise Soudní judikatura, 1997, který lze mutatis mutandis vztáhnout na všechny jednostranné právní úkony směrující k rozvázání pracovního poměru), že listina obsahující jednostranný právní úkon směřující k rozvázání pracovního poměru musí vždy obsahovat také vlastnoruční podpis účastníka právního vztahu, který pracovní poměr rozvazuje, popřípadě jeho zmocněnce; nevyhovuje-li listina tomuto požadavku, je rozvázání pracovního poměru neplatné.

Nejvyšší soud ze shora uvedených důvodů uzavřel, že byl-li dopis žalované ze dne 28. 2. 2012 obsahující výpověd’ z pracovního poměru danou žalobci opatřen toliko podpisovým razítkem statutárního orgánu (předsedy představenstva) žalované, aniž by

5 Zákon č. 65/1965 Sb., zákoník práce, ve znění účinném do 31. 12. 2006. 
obsahoval též vlastnoruční podpis této osoby, je předmětná výpověd’ z pracovního poměru ze dne 28.2. 2012 pro vadu formy právního úkonu podle ustanovení $§ 20$ odst. 3 ZPr neplatná.

V rámci diskuze občanskoprávního a obchodního kolegia Nejvyššího soudu byl vysloven oponentní názor zdůrazňující, že jde-li o podpis právnické osoby (jako tomu bylo v projednávané věci), pak identifikace jednajícího (jako jedna z funkcí podpisu) směřuje $\mathrm{k}$ právnické osobě, jež daný právní úkon činí. $\mathrm{Z}$ tohoto pohledu je zcela bez významu, zda je z písemného projevu vůle zřejmé, která fyzická osoba jej za právnickou osobu učinila. Jinak řečeno, označení osoby, která jedná za právnickou osobu, není ani náležitostí písemné formy, ani náležitostí podpisu právnické osoby. ${ }^{6}$ Nemusí-li být z písemného právního úkonu vůbec patrné, která fyzická osoba jej za právnickou osobu (jejím jménem) činí (stačí, aby šlo o fyzickou osobu, jež je k tomu oprávněna), pak ani v př́ípadě vlastnoručního podpisu (fyzické osoby jednající za osobu právnickou) nemusí adresát (zde zaměstnanec) vůbec vědět, kdo konkrétně daný právní úkon za právnickou osobu učinil. To přitom platí i pro výpověd z pracovního poměru danou zaměstnavatelem. O co více je zaměstnanec chráněn, bude-li u názvu (obchodní firmy) zaměstnavatele na výpovědi nečitelný podpis, než když tam bude např. otisk podpisového razítka člena statutárního orgánu? V čem tato ochrana spočívá? Nebude-li zřejmé, která osoba za zaměstnavatele jednala, bude $\mathrm{v}$ obou situacích tato okolnost podléhat (v př́ípadě sporu) dokazování (ponechávám nyní stranou, zda a příp. za jakých podmínek by zaměstnanci př́slušela námitka, že výpověd’ učinila za zaměstnavatele osoba, které nesvědčilo jednatelské či zástupčí oprávnění, a že jde tudíž o právní úkon, kterým zaměstnavatel není vázán).

Pracovní smlouva je soukromoprávní smlouvou, podléhající - v rozsahu, v němž zde není zvláštní právní úprava - občanskému zákoníku. I v řadě dalších vztahủ je jedna ze stran považována za slabší, a přesto není vyloučeno, aby písemné právní úkony jejího smluvního partnera byly podepisovány s využitím pravidla $\S 40$ odst. 3 věty druhé ObčZ 1964 (běžně se tak děje v mnoha spotřebitelských vztazích). Posledně označené ustanovení se plně uplatní i v pracovněprávních vztazích; rozhodující senát měl tudíž posuzovat, zda je (v poměrech projednávané věci) naplněn předpoklad obvyklosti. V této souvislosti pak nepovažuji za přiléhavý poukaz na praxi v období, kdy v rozporu s ústavním pořádkem (viz nález Ústavního soudu ze dne 12. 3. 2008, sp. zn. Pl. ÚS 83/06, uveřejněný pod č. 116/2008 Sb.) byla dovozována neaplikovatelnost občanského zákoníku na pracovněprávní vztahy a kdy se v důsledku toho pravidlo $§ 40$ odst. 3 věty druhé ObčZ 1964 nevyužívalo.

K vypořádání oponentního stanoviska zaznělo, že písemná forma právního úkonu (smlouvy) je bezpochyby dodržena, i když z něj není patrné, která fyzická osoba jej za právnickou osobu (jejím jménem) učinila (podepsala); z citovaných rozhodnutî ${ }^{7}$ se však

6 Srov. za všechna rozhodnutí rozsudky Nejvyššího soudu ze dne 29. 11. 2007, sp. zn. 29 Odo 965/2006 (uveřejněný pod číslem 92/2008 Sbírky soudních rozhodnutí a stanovisek), ze dne 30. 6. 2008, sp. zn. 29 Cdo 1971/2008, ze dne 27. 8. 2013, sp. zn. 21 Cdo 2186/2012; či usnesení Nejvyššího soudu ze dne 20. 2. 2019, sp. zn. 21 Cdo 4573/2018.

7 Rozsudky Nejvyššího soudu ze dne 29. 11. 2007, sp. zn. 29 Odo 965/2006 (uveřejněný pod číslem 92/2008 Sbírky soudních rozhodnutí a stanovisek), ze dne 30. 6. 2008, sp. zn. 29 Cdo 1971/2008, ze dne 
již nepodává, jaký význam má tento závěr z hlediska otázky možného nahrazení vlastnoručního podpisu osoby jednající za právnickou osobu mechanickým prostředkem. Právní názor zaujatý v rozhodnutí sp. zn. 21 Cdo 682/2018 se týká pouze a jen jednostranných právních úkonů zaměstnavatele směřujících k rozvázání pracovního poměru. Jak vyplývá z ustanovení § 4 ZPr, subsidiárně použitelné ustanovení § 40 odst. 3 ObčZ 1964 je třeba v pracovněprávních vztazích aplikovat a vyložit vždy v souladu se základními zásadami pracovněprávních vztahů, zejména zásadou zvláštní zákonné ochrany postavení zaměstnance. Vzhledem $\mathrm{k}$ této zásadě je třeba mít na zřeteli jednak význam jednostranných právních úkonů zaměstnavatele směřujících k rozvázání pracovního poměru se zaměstnancem, které zaměstnavatel činí bez ohledu na vưli zaměstnance a které snad nejzávažnějším způsobem zasahují do osobních i majetkových poměrů zaměstnance, a jednak možnou zneužitelnost příslušného mechanického prostředku jakoukoli fyzickou osobou, do jejíž dispozice se tento mechanický prostředek dostane. $Z$ tohoto hlediska nelze v pracovněprávních vztazích přijmout za obvyklé (posuzováno objektivně), že zaměstnavatel (osoba za něj jednající) na listině obsahující takto závažný jednostranný pracovněprávní úkon nahradí svůj vlastnoruční podpis (snadno zneužitelným) mechanickým prostředkem. Proto se v pracovněprávních vztazích u těchto rozvazovacích projevů vůle zaměstnavatele jeví - bez ohledu na to, zda je zaměstnavatel fyzickou či právnickou osobou - jako opodstatněné nadále (i podle právní úpravy účinné od 1. 1. 2007) klást přísnějšś požadavky na náležitosti jejich písemné formy a nepřipustit nahrazení vlastnoručního podpisu zaměstnavatele (osoby za něj jednající) mechanickými prostředky. Mezi vlastnoručním ,nečitelným“ podpisem osoby oprávněné jednat za zaměstnavatele a otiskem jejího podpisového razítka je rozdíl, nebot' v prvním př́ípadě jde o skutečný (pravý) podpis osoby oprávněné jednat za zaměstnavatele (i přes jeho nečitelnost), zatímco ve druhém př́padě jde jen o „podpis“ vyhotovený mechanickým prostředkem (nikoli vlastnoruční), který může na písemnost připojit nejen oprávněná osoba, ale i kdokoli jiný (na pokyn oprávněné osoby nebo s jejím vědomím, ale i bez jejího pokynu a vědomí). Konečně k námitce, že nelze považovat za přiléhavý „poukaz na praxi v období, kdy v rozporu s ústavním pořádkem (viz, nález Ústavního soudu ze dne 12.3.2008, sp. zn.Pl.ÚS 83/06, uveřejněný pod č. 116/2008 Sb.) byla dovozována neaplikovatelnost občanského zákoníku na pracovněprávní vztahy a kdy se v di̊sledku toho pravidlo $\$ 40$ odst. 3 věty druhé obč. zák. nevyuživalo (viz odst. 20 odi̊vodnění) “, je nutné uvést, že závěr ustálené judikatury Nejvyššího soudu, podle něhož právní úprava pracovněprávních vztahů v době do 31. 12. 2006, jež byla obsažena především v zákoníku práce, vycházela z úplné samostatnosti pracovního práva vůči občanskému právu (i ostatním odvětvím práva) a právní předpisy z tohoto dủvodu ani nevymezovaly vztah mezi zákoníkem práce a občanským zákoníkem a neupravovaly ani možnost analogického používání zákoníku práce $\mathrm{v}$ občanskoprávních vztazích či občanského zákoníku ve vztazích pracovněprávních, ${ }^{8}$ nebyl v žádném nálezu Ústavního soudu shledán v rozporu s ústavním pořádkem a že neústavním nebyl shledán ani ZPr 1965. Naopak,

27. 8. 2013, sp. zn. 21 Cdo 2186/2012; či usnesení Nejvyššího soudu ze dne 20. 2. 2019, sp. zn. 21 Cdo $4573 / 2018$.

8 Srov. například rozsudek Nejvyššího soudu ze dne 20. 9. 2001, sp. zn. 21 Cdo 2708/2000, který byl uveřejněn pod R 69/2002; nebo rozsudek Nejvyššího soudu ze dne 8. 4. 2010, sp. zn. 21 Cdo 1084/2009. 
Ústavní soud ve svém nálezu ze dne 2.7. 1996, sp. zn. I. ÚS 27/96, uzavřel, že v zásadně kogentní povaze pracovněprávních předpisů lze spatřovat jeden z podstatných rozdílů mezi nimi a předpisy občanskoprávními, že v př́ípadě, že pracovněprávní předpisy účastníkům pracovněprávních vztahů neumožňují odchylnou úpravu vzájemných práv a povinností, je třeba to, co těmto předpisům nevyhovuje, považovat za zakázáno, že tato kogentnost má své místo i v současné době, nebot' - i při rovnosti obou účastníků pracovněprávního vztahu před zákonem - zaměstnavatel je a bude i nadále pars potentior, takže ochrana zaměstnanců i touto formou má své opodstatnění, a že Ústavní soud neshledává protiústavnost v názoru obecných soudů, pokud jde o odlišování oblastí občanskoprávní a pracovněprávní regulace ve stávajícím právním řádu, nebot' právní úprava oblasti pracovněprávních vztahů se vyznačuje některými specifickými rysy. Jiné závěry ve vztahu k ZPr 1965 a rozhodovací praxi k němu se vztahující nevyplývají ani z nálezu Ústavního soudu ze dne 12.3. 2008, sp. zn. Pl. ÚS 83/06, v němž Ústavní soud posuzoval ústavnost některých ustanovení nynějšího zákoníku práce.

Občanskoprávní a obchodní kolegium Nejvyššího soudu předkládané rozhodnutí schválilo do Sbírky soudních rozhodnutí a stanovisek s právní větou, podle níž nahrazení vlastnoručního podpisu zaměstnavatele na výpovědi z pracovního poměru mechanickými prostředky není př́ípustné. Oponentní názor byl procedurálně uplatněn jako odlišné stanovisko ke schválenému usnesení. Byt' byl uvedený právní názor zaujat v poměrech ObčZ 1964, má svůj význam i za účinnosti ObčZ, kdy k otázce platnosti pracovněprávních jednání se Nejvyšší soud vyjádřil v rozsudku ze dne 27. 11. 2018, sp. zn. 21 Cdo 2576/2018. Významný je ovšem i potud, že je dalším př́íspěvkem k otázce, jakou roli má pracovní právo v systému soukromého práva s připomenutím základních zásad pracovního práva, které představují hodnotu chránící veřejný pořádek.

JUDr. Lubomír Ptáček, Ph.D.

předseda senátu Nejvyššího soudu

prezident Evropské asociace soudců pracovněprávních soudů

(The European Association of Labour Court Judges) 